\title{
Piperlongumine inhibits migration and proliferation of castration-resistant prostate cancer cells via triggering persistent DNA damage
}

Ding-fang Zhang ${ }^{1 \dagger}$, Zhi-chun Yang ${ }^{1,2+}$, Jian-qiang Chen ${ }^{1+}$, Xiang-xiang Jin ${ }^{1}$, Yin-da Qiu', Xiao-jing Chen ${ }^{1}$, Hong-yi Shi ${ }^{1}$, Zhi-guo Liu', Min-shan Wang ${ }^{3,4}$, Guang Liang ${ }^{1 *}$ and Xiao-hui Zheng ${ }^{1 *}$

\begin{abstract}
Background: Metastatic castration-resistant prostate cancer (CRPC) is the leading cause of death among men diagnosed with prostate cancer. Piperlongumine (PL) is a novel potential anticancer agent that has been demonstrated to exhibit anticancer efficacy against prostate cancer cells. However, the effects of PL on DNA damage and repair against CRPC have remained unclear. The aim of this study was to further explore the anticancer activity and mechanisms of action of PL against CRPC in terms of DNA damage and repair processes.

Methods: The effect of PL on CRPC was evaluated by MTT assay, long-term cell proliferation, reactive oxygen species assay, western blot assay, flow cytometry assay (annexin V/PI staining), $\beta$-gal staining assay and DAPI staining assay. The capacity of PL to inhibit the invasion and migration of CRPC cells was assessed by scratchwound assay, cell adhesion assay, transwell assay and immunofluorescence (IF) assay. The effect of PL on DNA damage and repair was determined via IF assay and comet assay.
\end{abstract}

Results: The results showed that PL exhibited stronger anticancer activity against CRPC compared to that of taxol, cisplatin (DDP), doxorubicin (Dox), or 5-Fluorouracil (5-FU), with fewer side effects in normal cells. Importantly, PL treatment significantly decreased cell adhesion to the extracellular matrix and inhibited the migration of CRPC cells through affecting the expression and distribution of focal adhesion kinase (FAK), leading to concentrationdependent inhibition of CRPC cell proliferation and concomitantly increased cell death. Moreover, PL treatment triggered persistent DNA damage and provoked strong DNA damage responses in CRPC cells.

Conclusion: Collectively, our findings demonstrate that PL potently inhibited proliferation, migration, and invasion of CRPC cells and that these potent anticancer effects were potentially achieved via triggering persistent DNA damage in CRPC cells.

Keywords: Castration-resistant prostate cancer, Piperlongumine, Cancer migration, DNA damage, DNA repair, DNA damage response

\footnotetext{
*Correspondence: wzmcliangguang@163.com; zhengxh@wmu.edu.cn

${ }^{\dagger}$ Ding-fang Zhang, Zhi-chun Yang and Jian-qiang Chen contributed equally

to this work.

'Chemical Biology Research Center, School of Pharmaceutical Sciences,

Wenzhou Medical University, Wenzhou 325035, Zhejiang, People's Republic of China

Full list of author information is available at the end of the article
}

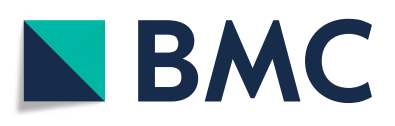

(- The Author(s). 2021 Open Access This article is licensed under a Creative Commons Attribution 4.0 International License, which permits use, sharing, adaptation, distribution and reproduction in any medium or format, as long as you give appropriate credit to the original author(s) and the source, provide a link to the Creative Commons licence, and indicate if changes were made. The images or other third party material in this article are included in the article's Creative Commons licence, unless indicated otherwise in a credit line to the material. If material is not included in the article's Creative Commons licence and your intended use is not permitted by statutory regulation or exceeds the permitted use, you will need to obtain permission directly from the copyright holder. To view a copy of this licence, visit http://creativecommons.org/licenses/by/4.0/. The Creative Commons Public Domain Dedication waiver (http://creativecommons.org/publicdomain/zero/1.0/) applies to the data made available in this article, unless otherwise stated in a credit line to the data. 


\section{Background}

Castration-resistant prostate cancer (CRPC), which develops from prostate cancer but is resistant to androgendeprivation therapy [1], is the leading cause of death in prostate cancer $[2,3]$. The high mortality rate of CRPC is mainly due to metastases to the bone and/or brain [4, 5]. Currently, mainstay treatments for CRPC include surgery, chemotherapy, radiotherapy, and immunotherapy $[1,6]$. Among them, chemotherapy is the first choice for oncologists in terms of treating metastatic CRPC. The majority of approved chemotherapeutic drugs kill cancer cells by introducing a DNA damage response [7]. Cancer cells are endowed with a similar or even stronger innate DNA-repair capacity compared to that of normal cells [8], which can limit the effectiveness of approved agents in treating cancer and/or may lead to chemotherapy failure [9]. With these concerns, an inexpensive reagent that enhances DNA damage and inhibits DNA repair may have a potential advantage as a CRPC therapeutic drug, as identification of drugs that target DNA damage with low side effects in normal cells remains a challenge in CRPC chemotherapy.

Piperlongumine (PL) is a natural antibacterial compound that is readily available, is inexpensive, and has long been used in Chinese herbal and Indian Ayurvedic medicine [10]. Recently, PL has received increased attention from researchers due to its anticancer effects [11, 12]. Mechanistic investigations have revealed that PL achieves anticancer effects via a reactive oxygen species (ROS)-dependent pathway [13] and modulates related signaling pathways, including MAPK, NF- $\mathrm{kB}$, and STAT3 pathways [14-20]. In the last decade, PL has been demonstrated to exhibit anticancer efficacies as well as sensitize the anticancer activities of chemotherapeutic drugs (e.g., doxorubicin) against prostate cancer cells $[14,21,22]$. However, the effects of PL on DNA damage and repair in CRPC cells have remained unclear. Hence, our present study investigated and identified the effects of PL on DNA damage and repair in CRPC PC3 and DU145 cells, which are derived from bone and brain metastasis of CRPC.

\section{Methods}

\section{Cell cultures and reagents}

CRPC cells (PC3 and DU145), the human normal prostatic stromal myofibroblast cell line (WPMY-1), and the human normal hepatic cell line (LO2) were purchased from the Cell Resource Center of Peking Union Medical College. Cells were maintained at $37^{\circ} \mathrm{C}$ with $5 \% \mathrm{CO}_{2}$ in Dulbecco's modified eagle's medium (DMEM; Gibco) that was supplemented with $10 \%$ fetal calf serum (PPA-GE, Marlborough, MA), as well as $100 \mathrm{U} / \mathrm{mL}$ of penicillin and streptomycin (HyClone-GE, Marlborough, MA). N-acetylL-cysteine (NAC) was purchased from Beyotime Biotech
(China). PL was obtained from Sigma-Aldrich (Item Number: SML0221), with a purity of $\geq 97 \%$.

\section{Determination of cell viability}

The cell viabilities of PC3, DU145, WPMY-1, and LO2 cells were assessed via 3-(4,5-dimethylthiazol-2-yl)-2,5diphenyltetrazolium bromide (MTT) assays [23]. Cells $\left(4 \times 10^{3}\right.$ cells/well in 96-well plates) were incubated at $37^{\circ} \mathrm{C}$ with or without PL treatment for $48 \mathrm{~h}$, after which MTT $(0.5 \mathrm{mg} / \mathrm{mL})$ was added at $20 \mu \mathrm{L} /$ well for another $4 \mathrm{~h}$. The reaction product, formazan, was dissolved in $100 \mu \mathrm{L}$ of DMSO after discarding the culture medium. Cell viability was determined by reading the absorbance at $560 \mathrm{~nm}$ by a spectrophotometer (DTX880, Beckman Coulter, CA, USA).

\section{Cell adhesion assays}

Cell adhesion assays were performed as described previously [24]. A 96-well plate was coated with $50 \mu \mathrm{L}$ of human fibronectin $(2.5 \mu \mathrm{g} / \mathrm{mL})$ in $1 \times$ PBS (Millipore, CA) at $4{ }^{\circ} \mathrm{C}$ overnight. Cells were seeded into a 96-well plate at a density of $4 \times 10^{4}$ cells/well and were cultured for another $1 \mathrm{~h}$ at $37^{\circ} \mathrm{C}$ in an incubator with $5 \% \mathrm{CO}_{2}$. Cells were then rinsed three times with $10 \%$ formalin and stained with crystal violet for $5 \mathrm{~min}$ at room temperature. After three washes with double-distilled $\mathrm{H}_{2} \mathrm{O}\left(\mathrm{dd}_{2} \mathrm{O}\right)$, stained cells were dissolved in $100 \mu \mathrm{L}$ of acetic acid (33\%). The absorbance at $560 \mathrm{~nm}$ was detected by a Synergy H1 MultiMode Reader (BioTek). The relative number of cells attached to the extracellular matrix was calculated using the following equation: mean optical density (OD) of treated cells/mean OD of control cells. Cells treated with vehicle $(0.01 \%$ DMSO) were used as a control.

\section{Transwell assays}

Transwell assays were performed as described previously [24] and carried out according to a purchased transwell kit (Corning Costar, NY) following the manufacturer's instructions. Briefly, cells were pretreated with different concentrations of PL for $48 \mathrm{~h}$ and were then reseeded into transwell permeable support (insert) pre-equilibrated with serum-free DMEM medium. For each group, $1 \times 10^{5}$ cells/ insert were seeded and incubated in $100 \mu \mathrm{L}$ of serum-free DMEM medium. The insert was then placed in a 24-well plate containing $600 \mu \mathrm{L}$ of DMEM medium with $10 \%$ FBS. After $24 \mathrm{~h}$ of culturing, cells on the upper surface of the insert were removed with cotton-tipped swabs. Then, the cells on the backside surface of the insert were fixed with $10 \%$ formalin, stained with crystal violet for $5 \mathrm{~min}$ at room temperature, and washed three times with $\mathrm{dd}_{2} \mathrm{O}$. Stained cells were dissolved in $500 \mu \mathrm{L}$ of acetic acid (33\%), and their absorbances were detected at $560 \mathrm{~nm}$ by a spectrophotometer (DTX880, Beckman Coulter, CA, USA). 


\section{Scratch-wound assays}

Cell scratch-wound assays were performed as described previously [24]. The cells were seeded in a six-well plate at a density of $3 \times 10^{5}$ cells/well and were cultured in medium containing PL or $0.01 \%$ DMSO for $48 \mathrm{~h}$. A denuded area was created across the diameter of the dish by a yellow tip. The cells were washed with PBS and then incubated in a serum-free medium. Phase-contrast images were acquired at the indicated times of incubation. Images were analyzed with Axiovision Rel.4.8 software. The percentage of areas covered by migrated cells (i.e., wound recovery) was calculated. Three independent experiments were carried out for quantification.

\section{Annexin V/PI apoptotic assays}

The Annexin V/PI method was applied for apoptotic assays (Sigma) following the manufacturer's instructions. Cells were seeded in $10 \mathrm{~cm}^{2}$ dishes at a density of $5.0 \times$ $10^{5}$ cells per dish and were incubated at $37^{\circ} \mathrm{C}$ overnight. $\mathrm{PL}$ at the indicated concentration was then added into the medium. After long-term cell proliferation assays or scratch-wound assays, cells were harvested for anexin $\mathrm{V} /$ PI apoptotic assays. These assays were performed following the protocol provided by the Annexin V/PI Apoptosis Kit (Sigma) and were assessed via a flow cytometer (BD FACS Calibur, BD Biosciences).

\section{Senescence-associated beta-galactosidase (SA- $\beta$ gal) activity}

A beta-galactosidase (SA- $\beta$ gal) staining kit was obtained from Sigma. The assay was performed following the manufacturer's instructions. In brief, cells were washed once with PBS and fixed with stationary liquid provided in the kit at room temperature for $15 \mathrm{~min}$. Next, the cells were incubated overnight at $37^{\circ} \mathrm{C}$ in the dark with $1 \mathrm{~mL}$ of a working solution containing $0.05 \mathrm{mg} / \mathrm{ml}$ of 5 bromo-4-chloro-3-indolyl-b-d-galactopyranoside (X-gal). Subsequently, the cells were observed under a normal light microscope (Nikon, Japan).

\section{Long-term cell proliferation assays}

Long-term cell proliferation assays were performed according to a previous study [25]. Long-term cell proliferation experiments were carried out in PC3 and DU145 cancer cell lines. First, $5.0 \times 10^{5}$ cells were seeded into $10-\mathrm{cm}^{2}$ dishes and incubated for $6 \mathrm{~h}$ to ensure that cells were completely adherent to the extracellular matrix. Second, PL at the indicated concentrations (i.e., 1.0, 2.0. or $4.0 \mu \mathrm{M})$ or DDP $(4.0 \mu \mathrm{M})$ was added to the medium for another $72 \mathrm{~h}$. Third, the cells were harvested, and the total number of cells was then counted. Finally, $5.0 \times 10^{5}$ cells were reseeded into $10-\mathrm{cm}^{2}$ dishes, and the above steps were repeated. The medium was changed every 3 days until confluence was reached. Quantification was performed as follows: $2^{\mathrm{PDs}}=\mathrm{M} / \mathrm{N}$, where PDs denote population doublings, $\mathrm{M}$ is the number of counted cells, and $\mathrm{N}$ is the number of implanted cells.

\section{Immunofluorescence (IF) assays}

Immunofluorescence (IF) assays were performed as previously described [26]. Briefly, cells were fixed with 4\% paraformaldehyde and permeabilized via $0.5 \%$ Triton X-100. Subsequently, cells were incubated with primary antibodies against focal adhesion kinase (FAK; CST) or 53BP1 (CST) and were then incubated with secondary antibodies (DyLight 488-conjugated anti-Rabbit). The cells were mounted with DAPI and/or phalloidin (CST). Fluorescent images were captured with a Nikon Ti microscope.

\section{Reactive oxygen species (ROS) assays}

ROS was quantified using a ROS kit (Sigma) according to the manufacturer's instructions. Cellular ROS levels were measured by flow cytometry. Briefly, $2 \times 10^{5}$ cells were plated onto six-well cell culture plates and allowed to attach to the wells overnight. Thereafter, adhered cells were treated with PL (1.0, 2.0, or $4.0 \mu \mathrm{M})$ in the presence or absence of NAC ( $5 \mathrm{mM})$ pre-treatment for $2 \mathrm{~h}$. After removal of the medium, the ROS indicator, DCFH-DA $(10 \mu \mathrm{M})$, was added to fresh FBS-free medium and incubated for $30 \mathrm{~min}$ at $37^{\circ} \mathrm{C}$ in the dark. Cells were then collected, and fluorescence was analyzed using a FACS Calibur flow cytometer (BD Biosciences, CA).

\section{DAPI staining}

After long-term cell proliferation assays, PC3 and DU145 cells were re-seeded in six-well cell culture plates at a density of $5 \times 10^{5}$ cells/well. After $6 \mathrm{~h}$ of incubation (during which cells adhered completely to the extracellular matrix), cells were fixed with $4 \%$ paraformaldehyde at room temperature for approximately $15 \mathrm{~min}$, after which they were washed three times with PBS prior to DAPI staining. Cells were observed using a Nikon fluorescent microscope.

\section{Comet assays}

DNA damage was evaluated by comet assays [27]. Cells were first mixed with $0.5 \%$ low-melting-temperature agarose before being transferred onto slides, which were coated with $1.5 \%$ normal agarose. Then, cells on these slides were lysed in 2.5-M NaCl, 10-mM Tris (pH 8.0), 100-mM EDTA, 0.5\% Triton X-100, 1\% N-lauroylsarcosine, and 3\% DMSO. Electrophoresis was carried out in 300-mM sodium acetate, 100$\mathrm{mM}$ Tris- $\mathrm{HCl}$, and $1 \%$ DMSO. The slides were then mounted with PI solution $(20 \mu \mathrm{g} / \mathrm{ml})$ and visualized under a Nikon fluorescent microscope and analyzed by CASP. 


\section{Western blotting}

Total proteins were extracted and boiled for $10 \mathrm{~min}$ at $95^{\circ} \mathrm{C}$. Samples were separated via SDS-PAGE gels, transferred to a PVDF membrane, and then blocked with 5\% nonfat milk in TBST for $2.5 \mathrm{~h}$ at room temperature. Blots were subsequently probed with relevant primary antibodies against FAK (CST), $\gamma$-H2AX (Millipore), cleaved PARP (CST), Bcl2 (Millipore), p53 (Santa), RPA (Santa), KU70 (Santa), XRCC4 (Santa) and $\beta$-actin (Proteintech) overnight at $4{ }^{\circ} \mathrm{C}$. Finally, the blots were detected with HRP-conjugated secondary antibodies and visualized using a Westar Supernova kit (Cyanagen).

\section{Statistical analysis}

GraphPad Prism 5 was used for statistical analysis. In histograms, all data were represented by mean \pm SD of at least three replicates for each experiment. The statistical significance of the data was assessed by student's twotailed unpaired $t$-test or Two-way ANOVA with the $p$ values $\left(" p<0.05 ;{ }^{* * *} p<0.01 ; * * * 0<0.001\right)$.

\section{Results}

PL possesses stronger anticancer activity than that of taxol, cisplatin (DDP), doxorubicin (dox), or 5-fluorouracil (5-FU) in CRPC cells, with fewer side effects in normal cells

First, the effects of PL on cell viabilities of CRPC cells (PC3 and DU145), the normal prostatic stromal myofibroblast cell line (WPMY-1) and the normal hepatic cell line (LO2) were evaluated. Taxol, DDP, Dox, and 5-FU were selected as positive-control drugs in the present study, as they are the most widely used chemotherapeutic drugs against CRPC that are used clinically. The results showed that PL possessed stronger or comparable anticancer activity with fewer side effects in normal cells when compared with those of all other positive-control drugs that were tested (Table 1 and Supplementary Figure 1).

Table $1 / C_{50}(\mu \mathrm{M})$ values were determined via the MTT assay ${ }^{a}$

\begin{tabular}{|c|c|c|c|c|}
\hline \multirow{2}{*}{$\begin{array}{l}\text { Cell lines / } \\
\text { compound }\end{array}$} & \multicolumn{4}{|l|}{$I C_{50}(\mu \mathrm{M})$} \\
\hline & PC3 & DU145 & WPMY-1 & LO2 \\
\hline$P L$ & $6.75 \pm 0.75$ & $8.42 \pm 0.98$ & $8.73 \pm 0.32$ & $68.62 \pm 5.38$ \\
\hline Taxol & $7.88 \pm 0.89$ & $7.26 \pm 0.69$ & $4.37 \pm 0.18$ & $34.70 \pm 1.03$ \\
\hline DDP & $27.81 \pm 4.53$ & $8.83 \pm 1.25$ & $7.43 \pm 0.85$ & $11.58 \pm 0.35$ \\
\hline Dox & $33.19 \pm 1.68$ & $41.50 \pm 1.15$ & $2.14 \pm 0.15$ & $80.61 \pm 3.89$ \\
\hline 5-FU & $96.33 \pm 1.86$ & $25.75 \pm 2.53$ & $97.24 \pm 2.03$ & $94.97 \pm 4.84$ \\
\hline
\end{tabular}

${ }^{\mathrm{a}} / C_{50}$ values were drug concentrations necessary for $50 \%$ inhibition of cell viability. Data are average \pm standard deviations of at least three independent experiments. The drug treatment period was $48 \mathrm{~h}$
PL inhibits CRPC cell migration by modulating the expression and distribution of FAK

Cell adhesion assays were performed to determine the capability of cells to adhere to the extracellular matrix with or without PL treatment. As shown in Fig. 1A and $\mathrm{B}, \mathrm{PL}$ treatment resulted in a significant concentrationdependent decrease in cell adhesion to the extracellular matrix at concentrations of 1.0, 2.0, and 4.0 $\mu \mathrm{M}$.

Cell adhesion is known to be correlated with cell migration [28]. Therefore, scratch-wound healing assays were performed to determine the migration rate of PC3 and DU145 cells with or without PL treatment. The data indicated that PL significantly inhibited cancer cell migration (Fig. $1 \mathrm{C}$ and E). After a 24-h treatment, only $15 \%$ of the scratch area was uncovered by migrated PC3 cells in the control group, while $71 \%$ of the scratch area was uncovered following treatment with $4.0 \mu \mathrm{M}$ of $\mathrm{PL}$ (Fig. 1D). Similarly, treatment with $4.0 \mu \mathrm{M}$ induced a significantly lower migration rate in PL DU145 cells (Fig. $1 F)$. To exclude the possibility of interference from cell death induced by PL, FACS assays and betagalactosidase (SA- $\beta$ gal) staining assays were used to evaluate apoptotic and senescent cells immediately after scratch-wound healing assays. The results showed that PL did not induce significant apoptosis or senescence during the cell migration assay (Supplementary Figure 2 ), indicating that PL-induced inhibition of cell migration was not induced by apoptosis/senescence.

In order to further determine the inhibitory effects of PL on PC3 and DU145 cell migration, transwell migration assays were carried out. The quantitative data suggested that PL-treated PC3 and DU145 cells possessed weaker transferability compared to that of untreated cells (Fig. 1G and $\mathrm{H}$ ). These results were consistent with the above results from our scratch-wound healing assays (Fig. 1).

Since precisely controlled cell deformations are vital to cell migration [29], we speculated that PL might affect the expression and function of cytoskeletal proteins in PC3 and DU145 cells. F-actin is not only the most abundant cytoskeletal protein but also a crucial protein for cell stability, morphogenesis, and motility [29]. Meanwhile, FAK is a cytoplasmic kinase that is essential for cell migration and morphogenesis [30]. Both F-actin and FAK contribute to cell migration and adhesion; hence, we speculated that PL might inhibit CRPC cell migration and adhesion by affecting the expression and distribution of FAK and F-actin. Therefore, IF and Western-blot assays were performed using FAK and phalloidin antibodies. The IF results showed that weak fluorescence (FAK) was observed in PL-treated cells, whereas FAK was expressed at a much higher level in the control group (Fig. 2A and Supplementary Figure 3A). Moreover, PL-treated cells presented a decreased cellspreading area in a concentration-dependent manner 


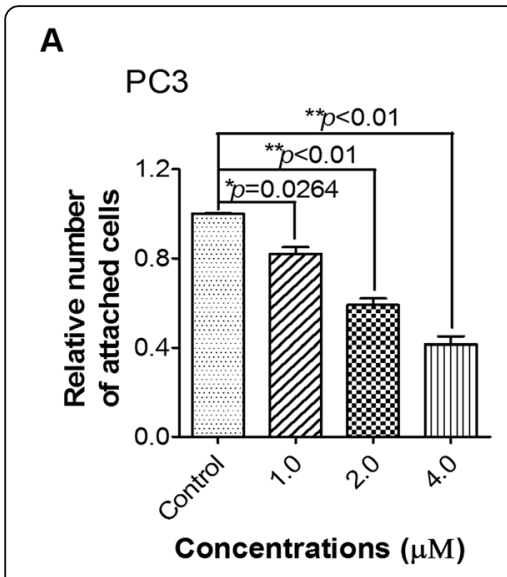

C

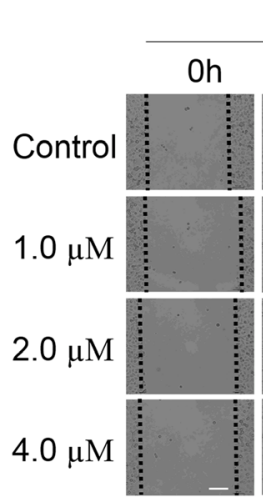

$\mathbf{F}$

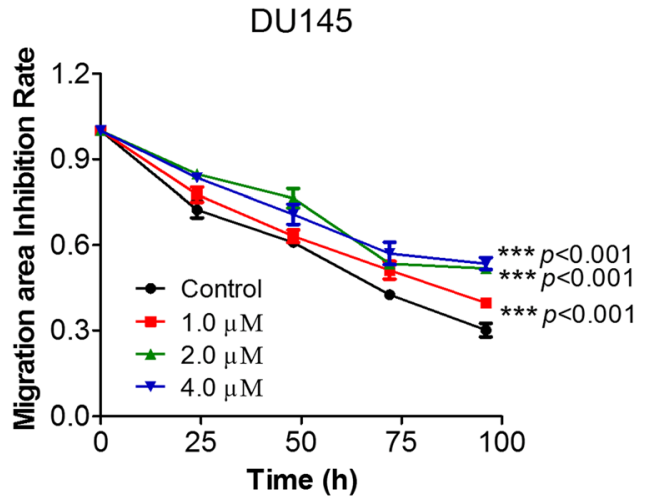

G
DU145

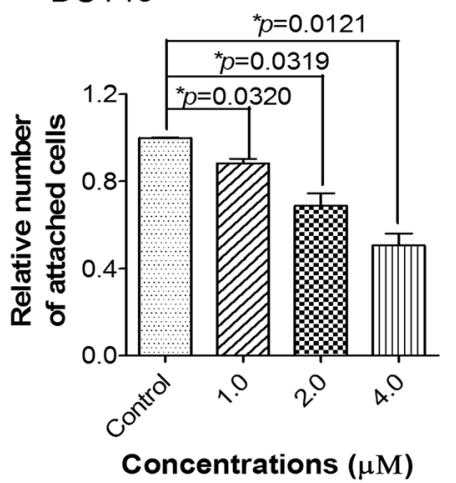

D

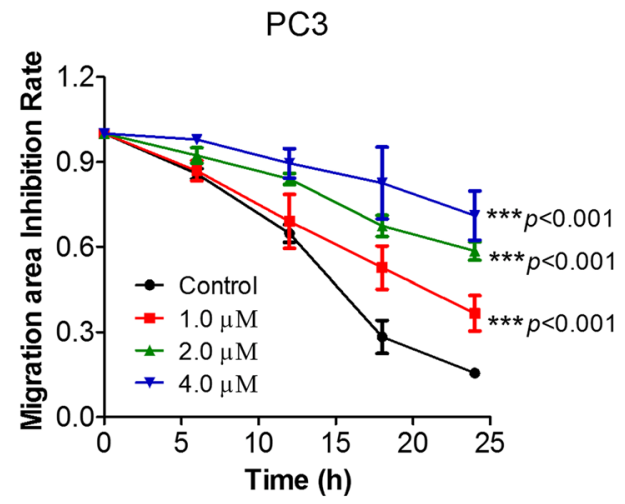

E

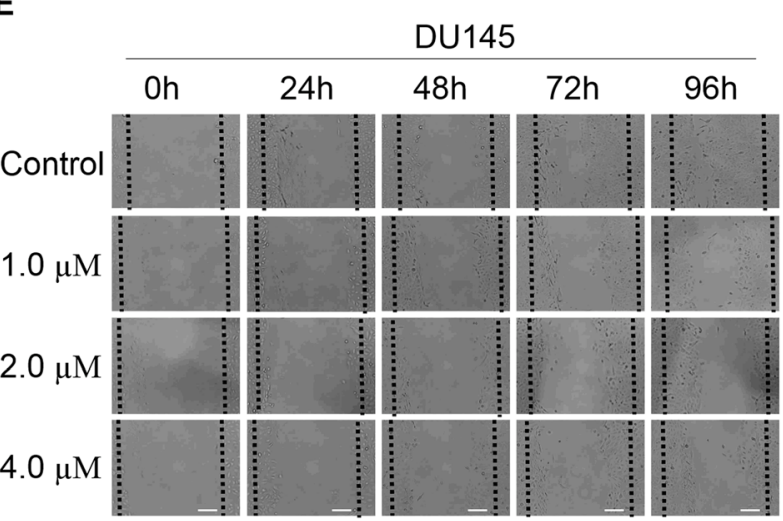

PC3

H
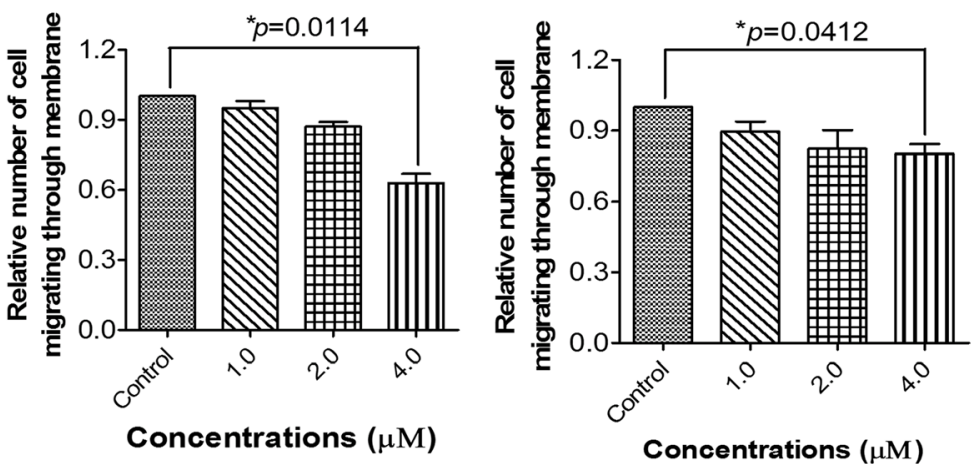

Fig. 1 PL inhibits the migration of CRPC cells. A and B, PL decreases cell adhesion to the extracellular matrix in PC3 and DU145 cells. C and $\mathbf{E}$, PL inhibits PC3 and DU145 cell migration in scratch-wound healing assays. The different time periods of PC3 and DU145 were adopted in scratch wound assay due to the difference migration speed between PC3 and DU145. Scale bar, $100 \mu \mathrm{m}$. D and F, Quantification of (C) and (E). G and $\mathbf{H}$, PL inhibits PC3 and DU145 migration in transwell assays. Values represent the mean \pm standard deviation (SD) of at least three independent experiments. Statistical significance was calculated using unpaired Student's two-tailed t tests for $\mathbf{A}, \mathbf{B}, \mathbf{G}, \mathbf{H}$, and two-way analysis of variance (ANOVA) for $\mathbf{D}$ and $\mathbf{F}$ with the $p$-values $\left({ }^{*} p<0.05,{ }^{* *} p<0.01,{ }^{* * *} p<0.001\right.$ )

(Fig. 2B and Supplementary Figure 3B). In addition, Western blotting further showed that PL efficiently decreased the expression of FAK, especially p-FAK (Fig. 2C-F). Taken together, these findings support the conclusion that PL inhibited the migration of CRPC cells via suppressing the expression and distribution of FAK at the edge of the cells.
PL effectively inhibits proliferation of CRPC cells and induces cell death by increasing ROS

High levels of ROS, which are correlated to cell fate, were found to induce both cell-cycle arrest and cell death in PL-treated PC3 and DU145 cells (Supplementary Figure 4). First, the effect of PL on cell proliferation 


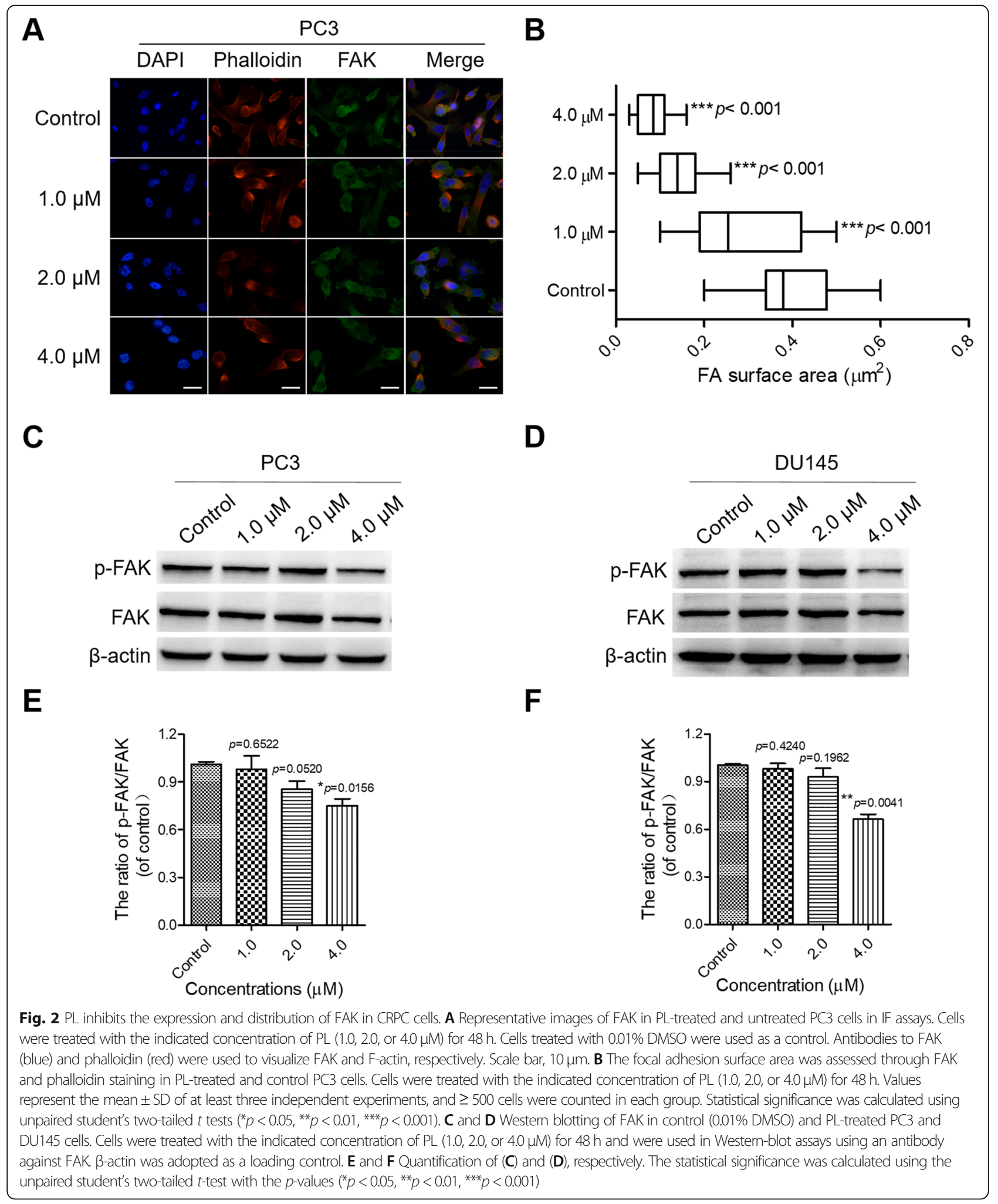

was determined by long-term cell proliferation assays. The results indicated that the proliferation of PC3 and DU145 cells was significantly inhibited by PL in a concentration-dependent manner (Fig. 3A and B). Since the induction of apoptosis is associated with modulation of PARP [31] and Bcl-2 [32], we also visualized cleaved PARP and Bcl2 content via Western blotting. The results indicated that PL treatment had no noticeable effect on 
A

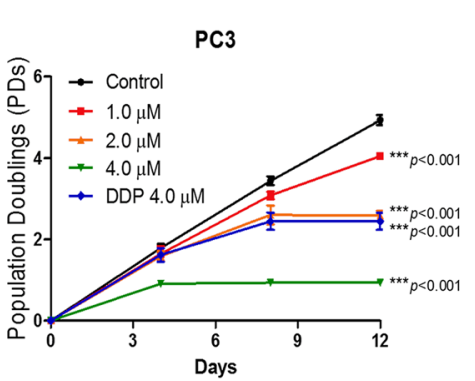

C PC3

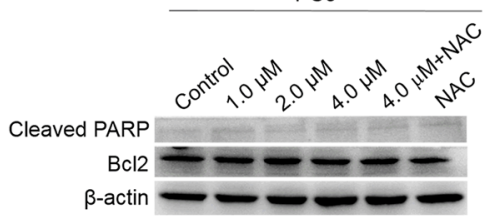

D

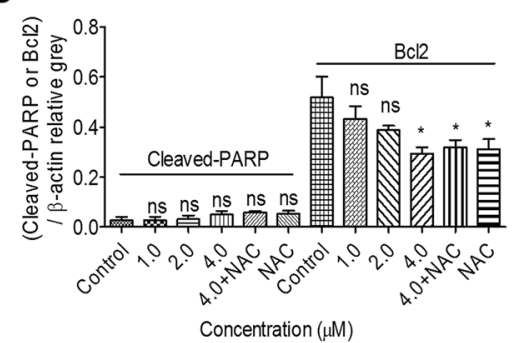

G

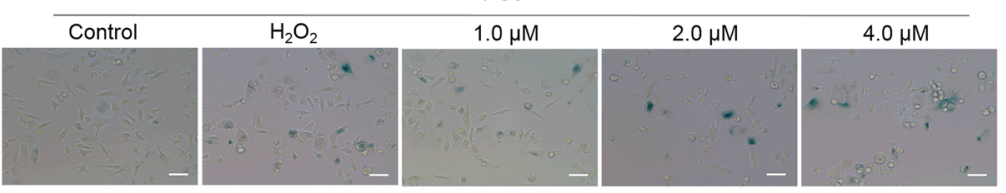

I

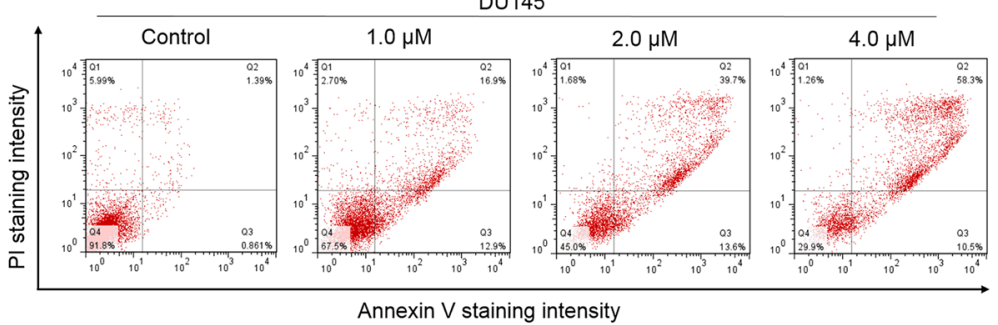

H

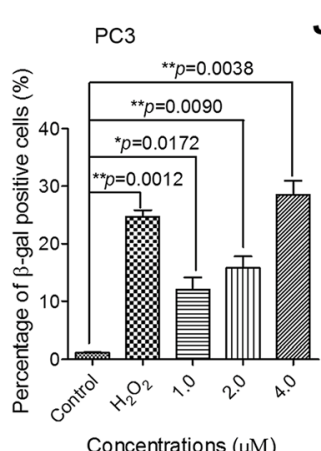

B

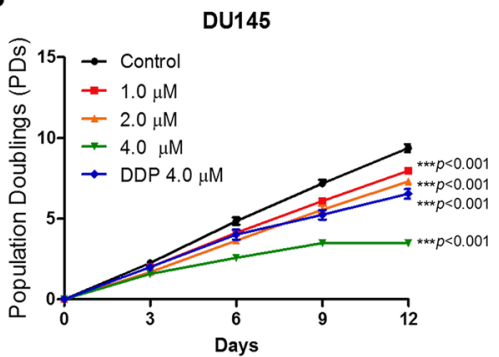

E

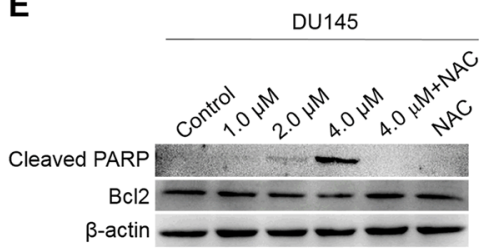

$\mathbf{F}_{\widehat{\mathrm{x}}}$

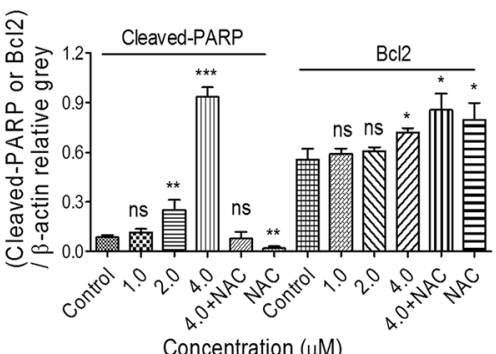

(1)

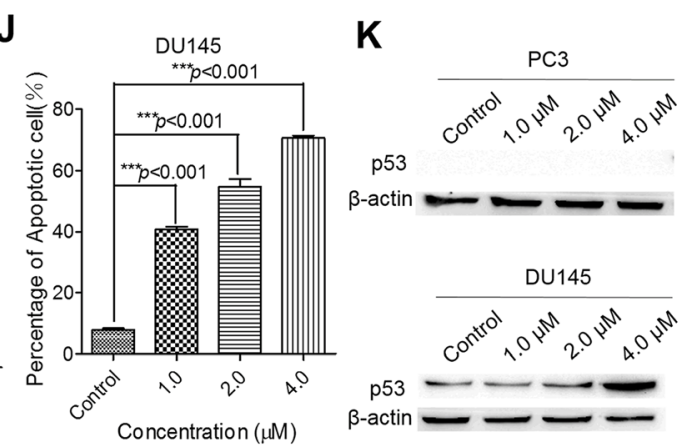

Fig. 3 (See legend on next page.) 


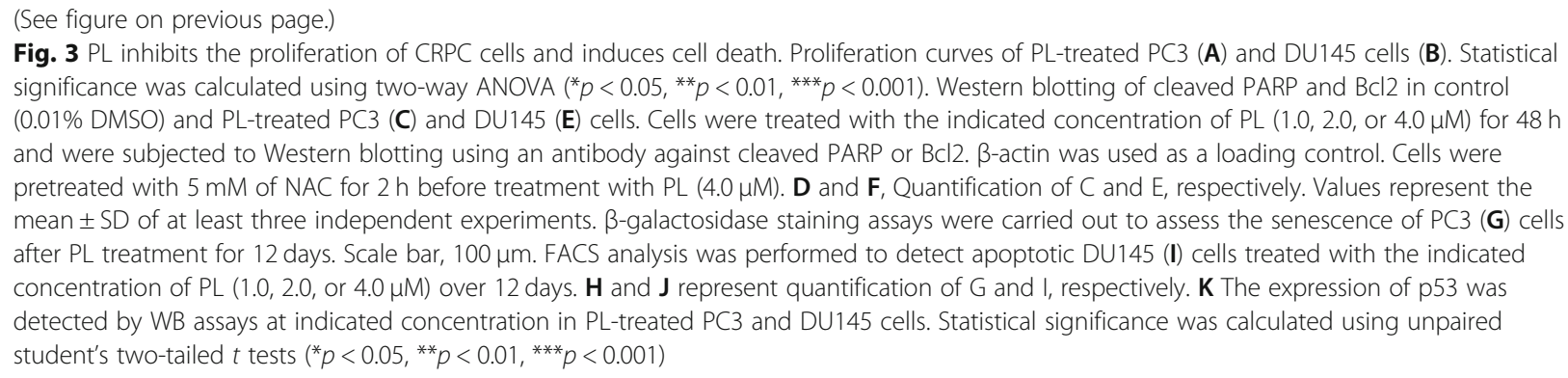

the expression of cleaved PARP but slightly downregulated the expression of $\mathrm{Bcl} 2$, an important antiapoptotic associated protein, in PC3 cells (Fig. 3C and D). Conversely, PL significantly increased the content of cleaved PARP protein at $4.0 \mu \mathrm{M}$ but had little effect on Bcl2 in DU145 cells (Fig. 3E and F). As expected, elevated cleaved PARP protein expression was absent after pretreatment with the ROS scavenger, $\mathrm{N}$-acetyl cysteine (NAC) (Fig. 3C and E). Taken together, these data indicate that PL treatment may result in different cell fates in PC3 and DU145 and that these effects are mediated by ROS, especially in PL-treated DU145 cells.

The status of the tumor-suppressor gene, p53, is null in PC3 cells but mutated in DU145 cells, and contributes to differential cell fates [33-35]. Therefore, both annexin V/PI apoptotic assays and SA- $\beta$ gal staining assays (Fig. 3G-J and Supplementary Figure 5) were carried out to detect the cell fates of PC3 and DU145 cells. $\mathrm{H}_{2} \mathrm{O}_{2}$ treated cells were used as a positive control (Fig. 3G and Supplementary Figure 5C). The flow cytometry results showed that immediately after long-term cell proliferation assays (PL treatment for 12 days), the apoptotic ratio was not changed in PL-treated PC3 cells (Supplementary Figure 5A and B), whereas PL significantly induced cell senescence (Fig. 3G and H). Conversely, PL treatment induced apoptosis in DU145 cells with concomitantly increased expression of p53 (Fig. 3I-K), while senescent cells were undetectable (Supplementary Figure 5C and D). Furthermore, we examined nuclear morphology in PL-treated or untreated CRPC cells immediately after long-term proliferation assays. The results showed that more than $70 \%$ of PL-treated DU145 cells had apoptotic nuclei $(73.2 \pm 2.1 \%)$, including condensed nuclei (Supplementary Figure 6). In contrast, PL-treated PC3 cells and controls appeared to exhibit intact ovalshaped morphologies, and their nuclei did not appear to be as apoptotic.

\section{PL treatment induces persistent DNA damage}

FAK and ROS can affect DNA damage as well as the DNA damage response (DDR) [36, 37], and unbalanced DNA damage and repair will result in apoptosis and/or senescence [33]. Therefore, comet assays and IF assays were carried out to examine the effects of PL on DNA damage and the DDR in CRPC cells. As expected, PL caused increased DNA damage in PC3 cells, resulting in DNA fragments that formed a tail shape during electrophoresis (Fig. 4A-C). These results were consistent with the data from our IF assays, which showed that the number of 53BP1 foci in PL-treated PC3 cells was significantly increased in a concentration-dependent manner (Fig. 4D and E). In addition, similar results were obtained in PL-treated DU145 cells (Supplementary Figure 7). The increased expression of $\gamma-\mathrm{H} 2 \mathrm{AX}$, a marker of DNA double strand breaks (DSB), in PL-treated CRPC cells (Fig. 4F-I) further supported the conclusion that PL triggered substantial DNA damage and the DDR in CRPC cells. Moreover, we found that PL treatment resulted in no change in amount of replication protein $\mathrm{A}$ (RPA), which plays a role in DNA strand invasion during homologous recombination (HR) [38]. In contrast, PL treatment suppressed the expression of KU70 and XRCC4, the marker of non-homologous end joining (NHEJ) [39], in a concentration-dependent manner (Supplementary Figure 8A and B). Additionally, we also tested DNA damage in PL-treated, positive-controltreated, or untreated human normal LO2 cells using an antibody against 53BP1; subsequently, the number of foci per nucleus was then calculated. Our data showed that compared to those following taxol, DDP, Dox, or 5-FU treatments, less 53BP1 foci were detected in PL-treated LO2 cells, indicating that PL induced less DNA damage in human normal LO2 cells (Supplementary Figure 9).

To explore the consequences of DNA damage, both PC3 and DU145 cells were treated with PL at a dose of $10 \mu \mathrm{M}$ for $3 \mathrm{~h}$. Cells under this condition did not exhibit any senescence (Supplementary Figure $10 \mathrm{~A}$ and B), apoptosis (Supplementary Figure $10 \mathrm{C}$ and D), or cellcycle arrest (Supplementary Figure 10E-H). After PL treatment, the media was immediately replaced with PLfree medium, and cells were fixed at the indicated times $(0,2,4,8,24$, or $48 \mathrm{~h})$. The fixed cells were then used in comet assays and IF assays. The data from comet assays showed that PL treatment triggered numerous DNA lesions in PC3 and DU145 cells, resulting in DNA lesions that left the nucleus and formed tail shapes during the 
A
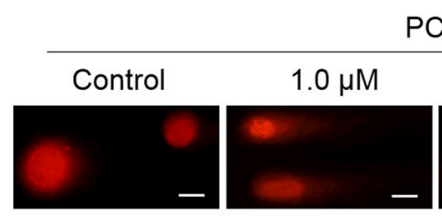

PC3

B

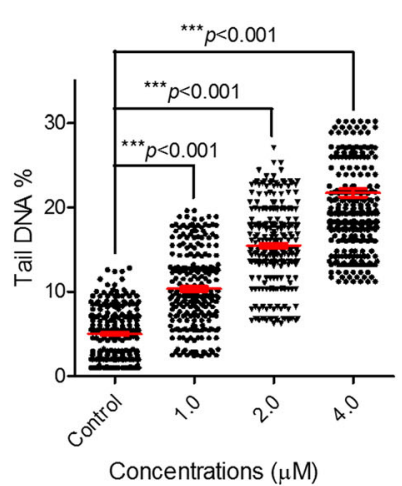

D

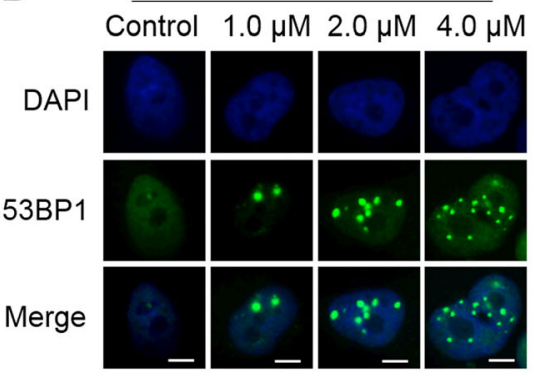

F

PC3

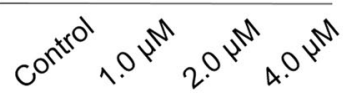

$\mathrm{Y}-\mathrm{H} 2 \mathrm{AX}$

$\beta$-actin

$$
=
$$

H

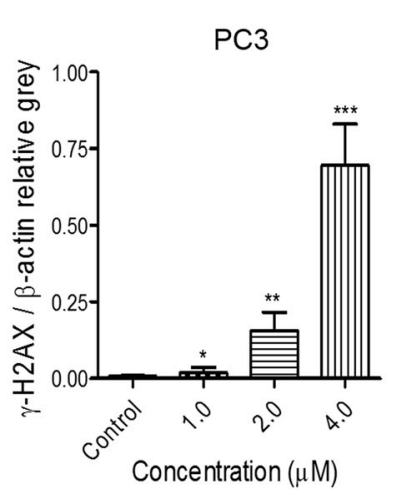

C

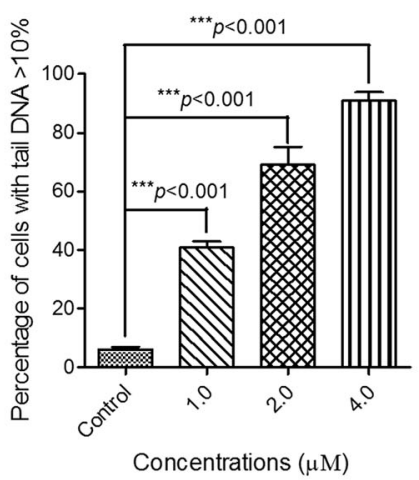

E

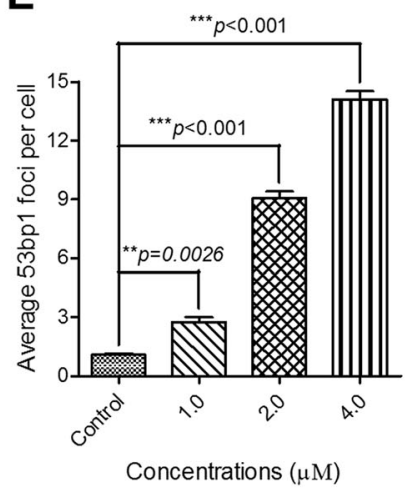

G

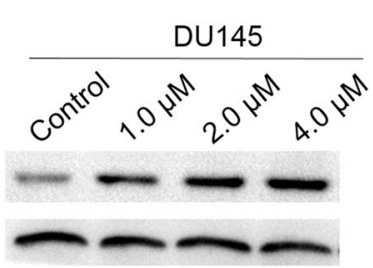

I

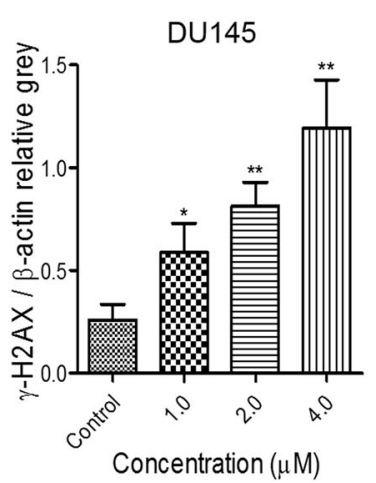

Fig. 4 (See legend on next page.) 
(See figure on previous page.)

Fig. 4 PL treatment triggers strong DNA damage and provokes an intense DDR in CRPC PC3 cells. A The data from comet assays show that PL treatment triggered strong DNA damage in a concentration-dependent manner. Scale bar, $100 \mu \mathrm{m}$. B and C, The percentages of tail DNA in PLtreated PC3 cells $(\mathbf{B})$ and the number of PL-treated PC3 cells containing more than 10\% tail DNA $(\mathbf{C})$ were measured. Cells were treated with the indicated concentration of PL (1.0, 2.0, or $4.0 \mu \mathrm{M})$ for $48 \mathrm{~h}$, and $\geq 500$ cells were examined in each group. $\mathbf{D}$ The IF data show that PL treatment provoked an intense DDR in a concentration-dependent manner. Scale bar, $10 \mu \mathrm{m}$. E Quantification of (D). Cells were treated with the indicated concentration of PL (1.0, 2.0, or $4.0 \mu \mathrm{M})$ for $48 \mathrm{~h}$, and $\geq 200$ cells were examined in each group. $\mathbf{F}$ and $\mathbf{G}$ Western blotting of $\gamma-\mathrm{H} 2 \mathrm{AX}$ in control (0.01\% DMSO) and PL-treated PC3 (F) and DU145 (G) cells. Cells were treated with the indicated concentration of PL $(1.0,2.0$, or $4.0 \mu \mathrm{M})$ for $48 \mathrm{~h}$ and were subjected to Western blotting using an antibody against $\gamma$-H2AX. $\beta$-actin was used as a loading control. $\mathbf{H}$ and $\mathbf{I}$, Quantification of (F) and $(\mathbf{G})$, respectively. Values represent the mean \pm SD of at least three independent experiments. The statistical significance was calculated using the unpaired student's two-tailed $t$-test with the $p$-values $\left({ }^{*} p<0.05,{ }^{* *} p<0.01,{ }^{* * *} p<0.001\right)$

comet assay (Fig. 5A). It is noteworthy that these tail shapes were still present within $48 \mathrm{~h}$ after PL treatment (Fig. 5B), suggesting suppressed repair of DNA damage in PL-treated CRPC cells and/or PL-induced persistent DNA damage in CRPC cells.
We also used IF assays to monitor DNA damage repair in PL-treated CRPC cells (Fig. 6A). The number of 53BP1 foci achieved the highest value at $4 \mathrm{~h}$ after PL treatment in both PC3 and DU145 cells (8 and 13 foci per nucleus, respectively) (Fig. 6B). However, these

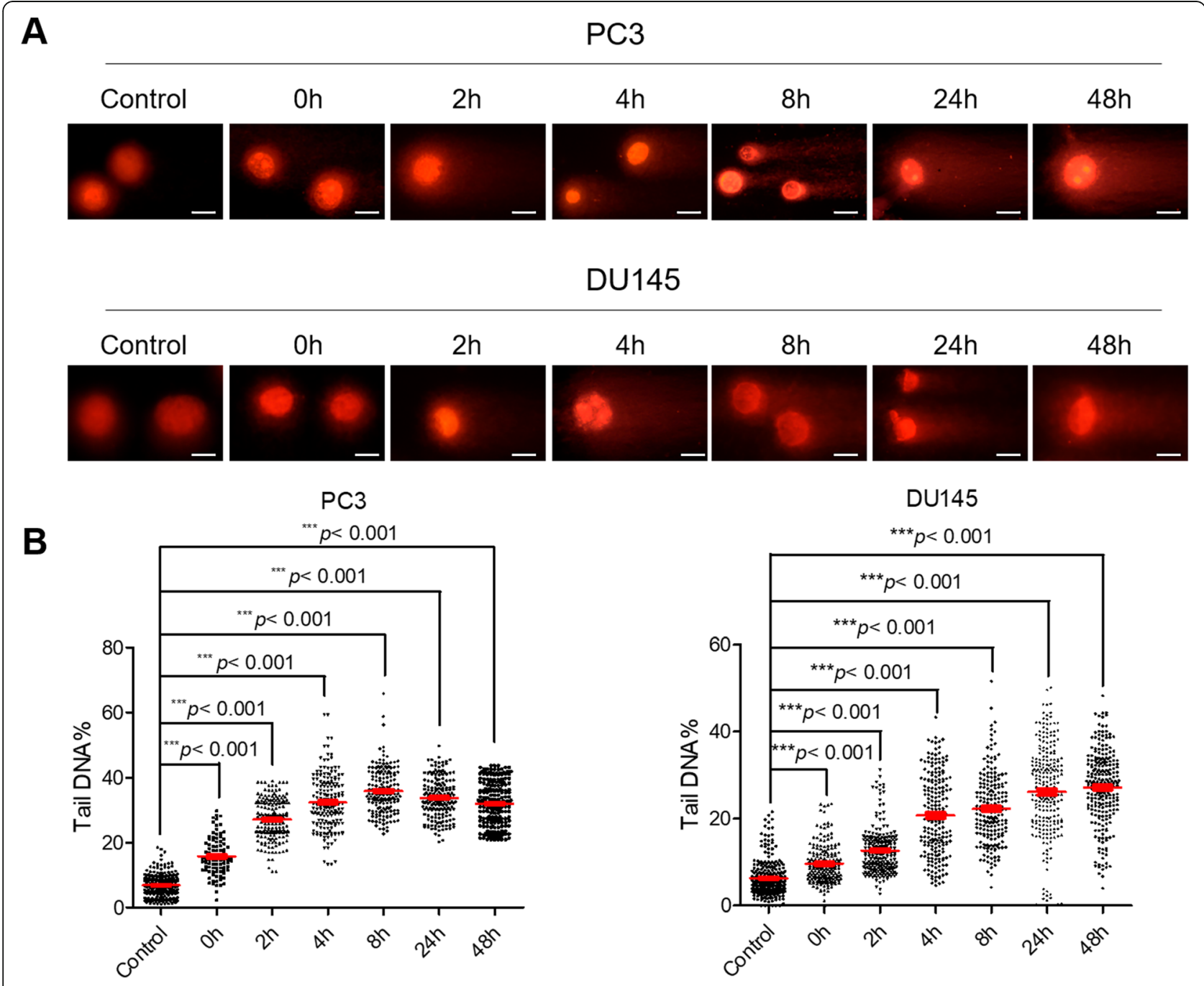

Fig. 5 PL-induced DNA damage is not repaired in CRPC PC3 and DU145 cells. A Representative images of DNA damage via comet assays. PC3 or DU145 cells were treated with PL $(10 \mu \mathrm{M})$ for $3 \mathrm{~h}$ and were then collected at the indicated times $(0,2,4,8,24$, or $48 \mathrm{~h})$. Scale bar, $100 \mu \mathrm{m}$. B The percentages of tail DNA in PL-treated PC3 or DU145 cells were measured. Values represent the mean \pm SD of at least three independent experiments, and $\geq 500$ cells were counted in each group. Statistical significance was calculated using unpaired Student's two-tailed $t$ tests $\left({ }^{*} p<0.05,{ }^{* *} p<0.01,{ }^{* * *} p<0.001\right)$ 
A

A PC3

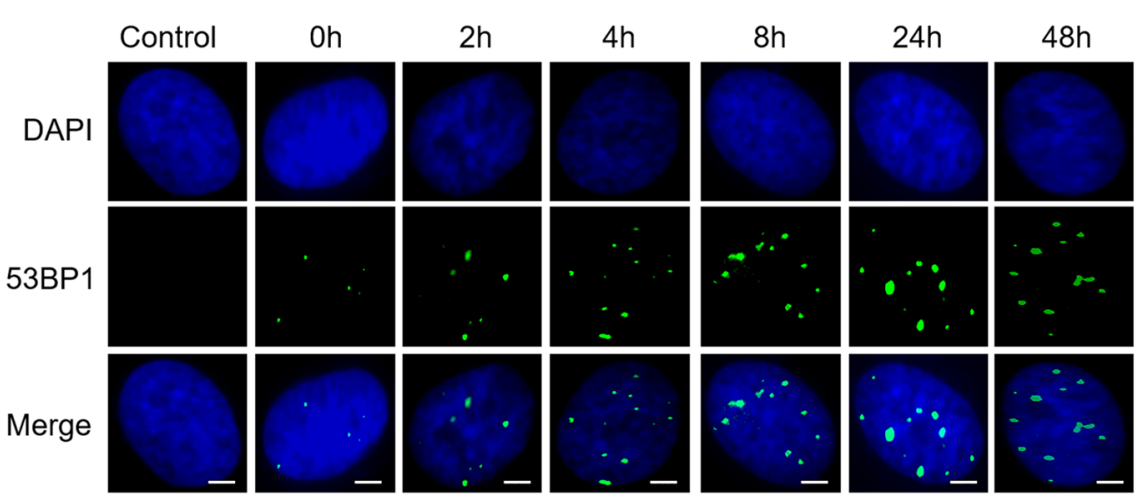

DU145

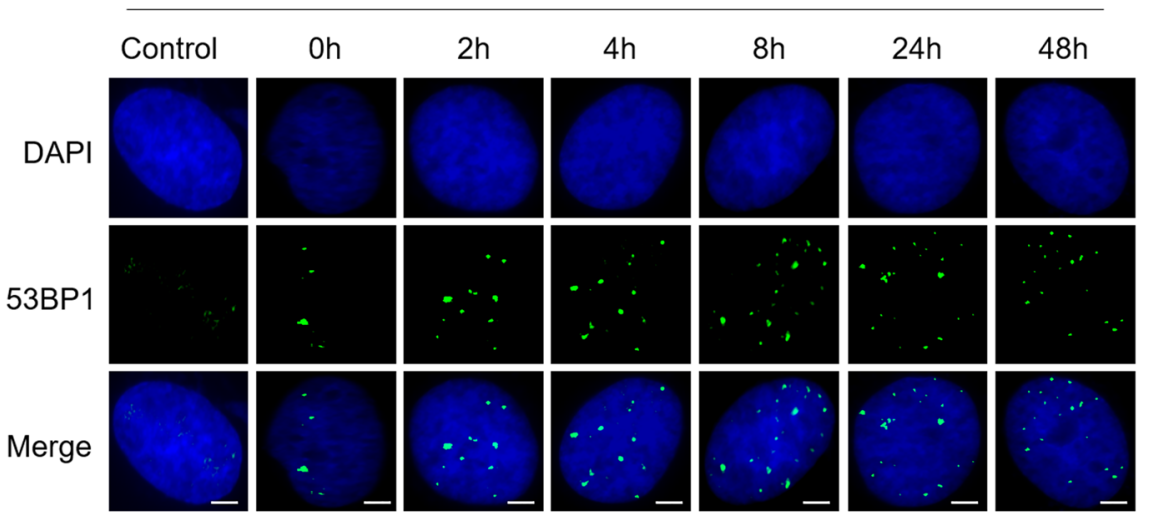

B

$\mathrm{PC} 3$

DU145
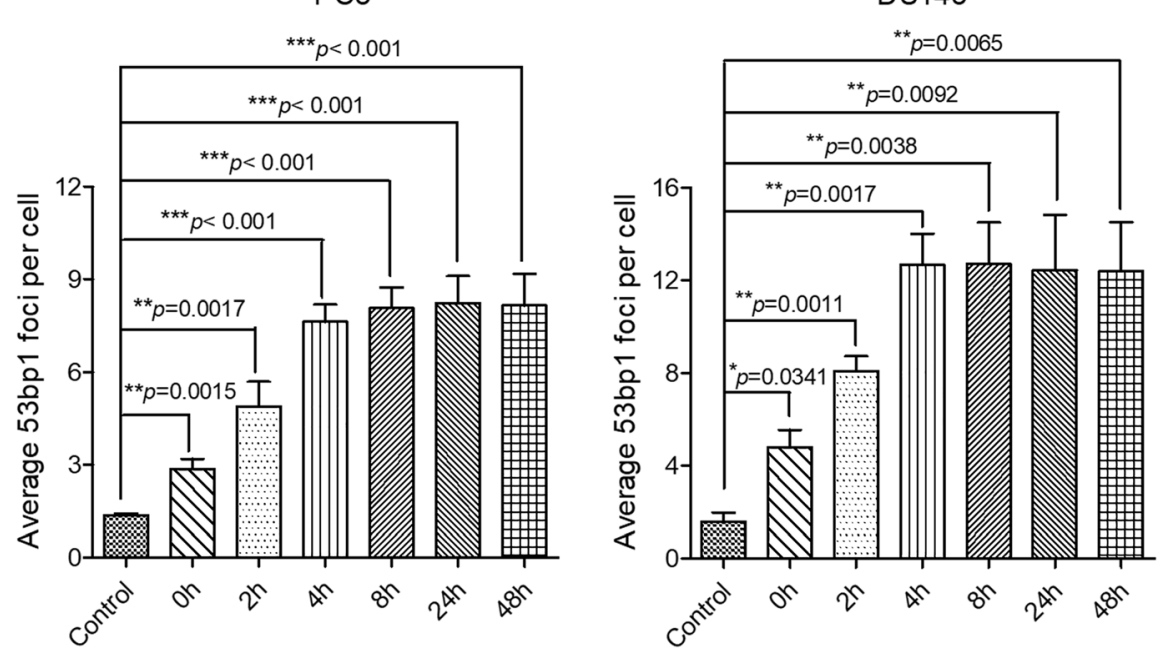

Fig. 6 DDR machinery is impaired in PL-treated CRPC cells. A Cells were exposed to PL (10 $\mu \mathrm{M})$ for $3 \mathrm{~h}$ and then replaced with PL-free medium for $0,2,4,8,24$, and $48 \mathrm{~h}$. Untreated cells served as a control. 53BP1 foci were calculated by IF using an 53BP1 antibody. Cell nuclei were stained using DAPI. Scale bar, $10 \mu \mathrm{m}$. B Quantification of (A). The average number of 53BP1 foci per cell was determined and $\geq 200$ cells were counted each group. Values are average \pm SD of at least three independent experiments. The statistical significance was calculated using the unpaired student's two-tailed $t$-test with the $p$-values $\left({ }^{*} p<0.05,{ }^{* *} p<0.01,{ }^{* * *} p<0.001\right)$ 
values were still maintained within $48 \mathrm{~h}$ after PLtreatment (Fig. 6A and B). Next, we performed western blots to examine the abundance of HR-related protein RPA and NHEJ-related protein XRCC4 in $10 \mu \mathrm{M}$ PL treated-PC3 and DU145 cells at different time $(0 \mathrm{~h}, 4 \mathrm{~h}$, $8 \mathrm{~h}, 24 \mathrm{~h}$ and $48 \mathrm{~h}$ ). The results showed that $10 \mu \mathrm{M} \mathrm{PL}$ treatment obviously reduced expression of RPA and XRCC4, and increased expression of p53 (Supplementary Figure 11A and B). These results revealed that DNA damage induced by PL may not be repaired in CRPC cells. Consequently, Annexin V/PI apoptotic assays indicated that $10 \mu \mathrm{M}$ PL significantly induces DU145 cells apoptosis in time-dependent manner, but slightly induces apoptosis in PC3 cells, which may attribute to the expression of p53 (Supplementary Figure 11C-F). Taken together, these data support the conclusion that PL treatment induced intense DNA damage in CRPC cells.

\section{Discussion}

Androgen deprivation (ADT) is a major strategy for mitigating advanced prostate cancer; however, the cure success rate of ADT is low, and most patients eventually develop CRPC [6]. Moreover, 90\% of CRPC patients develop metastases with a high mortality rate, for which chemotherapy is the preferred clinical treatment [1]. Chemotherapy achieves anticancer effects via causing substantial DNA damage [9]. However, chemotherapy often fails after long-time treatment due to enhanced capacities of DNA repair in cancer cells [9]. Additionally, long-time chemotherapy often leads to serious toxic side effects. Thus, there has been an urgent need to identify a chemotherapeutic drug that possesses preferential effects against cancer cells without causing serious adverse side effects in normal cells. Our present results indicate that PL exhibited a broad spectrum of antitumor activities in CRPC cells, independent of p53, and induced lower cytotoxicity than that of cisplatin or taxol in normal cells, as well in WPMY-1 and LO2 cells (Table 1 and Supplementary Figure 9).

Considering that migration is the leading cause of cancer-related deaths [5, 28], a drug capable of effectively inhibiting the migration of cancer cells has potential therapeutic value. In our present study, we demonstrated that PL-treated CRPC cells exhibited decreased adhesion to the extracellular matrix (Fig. 1A and B). Accordingly, a decreased migration speed (Fig. 1C-F) and an attenuated ability to traverse a membrane from the serum-free to serum side (10\% FBS) in the transwell assay (Fig. 1G and $\mathrm{H}$ ) were observed in PL-treated CRPC cells. FAK, a non-receptor protein tyrosine kinase, is overexpressed and activated in a majority of cancers, including prostate cancer. FAK localizes to focal adhesions and it is activated by extracellular signals including integrin-mediated adhesion, which further leads phosphorylation of Tyr397 and activate downstream signaling pathways, contributes to the metastasis and invasion of prostate cancer cells [40]. Our study showed that PL inhibited the expression and distribution of FAK at the leading edge of cells as well as inhibited phosphorylation of Tyr397, and PL-treated cells presented a decreased cell-spreading area in a concentration-dependent manner (Fig. 2 and Supplementary Figure 3). Given the importance of F-actin and FAK in cell adhesion and migration, we propose that PL inhibited the adhesion and migration of CRPC cells by suppressing the expression and distribution of FAK in CRPC cells. Therefore, FAK is a potential effective target to inhibit migration of prostate cancer.

Previous studies have demonstrated that PL exhibited potent anticancer effects by activating $\operatorname{ROS}[13,41]$ and high ROS levels induce substantial DNA damage [37]. Since the integrity of DNA is crucial to cell viability and metastasis of cancer cells, sufficient DNA damage can cause cell-cycle arrest and cell death [7]. The results of our present study indicated that PL suppressed CRPC cell proliferation and induced cell death (Fig. 3) at low concentrations (i.e., 1.0, 2.0, and $4.0 \mu \mathrm{M}$ ) by provoking intense DNA damage and inducing a strong DDR and inhibiting the DNA repair process (Fig. 4, Supplementary Figure 7 and Supplementary Figure 8). Furthermore, we found that the different cell fates of PL-treated PC3 (senescence) and DU145 (apoptosis) cells may be the result of multiple factors, including a differential p53 status between these cell types (Fig. 3K), as well as differential changes in PL-induced protein expression and apoptosis (Fig. 3C and D). Taken together, these data suggest that PL might achieve anticancer effects through ROS-mediated DNA damage and inhibition of repair pathways in a p53-independent manner. Therefore, the PL-induced fate of these DNA lesions in CRPC cells is worthy of further investigation.

Cancer cells have a high tolerance to genotoxicity via DNA repair and/or reversal of epigenetic defects [7]. In addition, an imbalance in redox equilibrium may cause serious DNA damage, and FAK inhibition can also result in persistent DNA damage $[36,37]$. As expected, our present results demonstrated that PL induced substantial DNA damage in CRPC cells (Figs. 5 and 6), which may have been attributed to a substantial imbalance in redox equilibrium (Supplementary Figure 4) and FAK inhibition (Fig. 2 and Supplementary Figure 3). In addition, DNA damage repair approach including HR and NHEJ for DSB were impeded in PL treated PC3 and DU145 cells (Supplementary Figure 8, Supplementary Figure $11 \mathrm{~A}$ and $\mathrm{B})$. As a result, substantial DNA damage and DDR accumulation-initiated inhibition of cell migration (Fig. 1) and a cell death response (Fig. 3). 


\section{Conclusions}

In conclusion, our present results found that PL efficiently inhibited the migration and proliferation of CRPC cells and induced cell death in a concentrationdependent manner. Moreover, the results indicated that PL treatment would regulate the expression and distribution of FAK and the intracellular ROS levels. Further mechanism studies showed that PL achieved both antiproliferation and anti-migration activities by triggering intense DNA damage in CRPC cells.

\section{Abbreviations}

CRPC: Castration-resistant prostate cancer; ADT: Androgen-deprivation therapy; DDP: Cisplatin; DDR: DNA damage response; Dox: Doxorubicin; 5FU: 5-Fluorouracil; MTT: 3-(4,5-dimethyl-2-thiazolyl)-2,5-diphenyl-2-Htetrazolium bromide; IF: Immunofluorescence; PARP: Poly (ADP-ribose) polymerase; PL: Piperlongumine; PSA: Prostate-specific antigen; ROS: Reactive oxygen species; FAK: Focal adhesion kinase; SA- $\beta$ gal: Senescence-associated beta-galactosidase activity

\section{Supplementary Information}

The online version contains supplementary material available at https://doi. org/10.1186/s12906-021-03369-0.

Additional file 1: Supplementary Figure 1. $I_{50}(\mu \mathrm{M})$ values were determined via the MTT assay. $/ C_{50}$ values were drug concentrations necessary for $50 \%$ inhibition of cell viability. Data are average \pm standard deviations of at least three independent experiments. The drug treatment period was $48 \mathrm{~h}$. Supplementary Figure 2. Piperlongumine ( $\mathrm{PL}$ ) treatment did not induce significant cell apoptosis or senescence after the cell migration assay. FACS analysis was performed to detect the apoptotic PC3 (A) and DU145 (C) cells after the scratch-wound assay with the indicated concentration of $\mathrm{PL}(1.0 \mu \mathrm{M}, 2.0 \mu \mathrm{M}$ or $4.0 \mu \mathrm{M})$. $\beta$ galactosidase staining assay was carried out to assess the senescence of PC3 (E) and DU145 (G) cells after the scratch-wound assay with the indicated concentration of PL $(1.0 \mu \mathrm{M}, 2.0 \mu \mathrm{M}$ or $4.0 \mu \mathrm{M})$. Scale bar, $100 \mu \mathrm{m}$. (B), (D), (F) and (H) were quantification of A, C, E and G, respectively. Values are average \pm SD of at least three independent experiments. The statistical significance was calculated using the unpaired student's twotailed t-test with the $p$-values $\left({ }^{*} p<0.05,{ }^{* *} p<0.01,{ }^{* * *} p<0.001\right)$. Supplementary Figure 3. Piperlongumine $(\mathrm{PL})$ inhibits the expression and distribution of focal adhesion kinase (FAK) in castration-resistant prostate cancer (CRPC) DU145 cells. (A), Representative images of focal adhesion kinase (FAK) in PL-treated and control DU145 cells in immunofluorescence assays. Cells were treated with the indicated concentration of PL for $48 \mathrm{~h}$. Cells treated with $0.01 \%$ DMSO were used as a control (Control). Antibody to FAK (blue) and phalloidin (red) were used to visualize FAK and F-actin, respectively. Scale bar, $10 \mu \mathrm{m}$. (B), Focal adhesion surface area assessed through FAK and phalloidin staining in PL-treated and control DU145 cells. Cells were treated with indicated concentration of PL $(1.0 \mu \mathrm{M}, 2.0 \mu \mathrm{M}$ or $4.0 \mu \mathrm{M})$ for $48 \mathrm{~h}$. Values are average \pm SD of three independent experiments and $\geq 500$ cells were examined in each group. The unpaired student's two-tailed t-test was used to determine the statistical significance $\left({ }^{*} p<0.05,{ }^{* *} p<0.01\right)$. Supplementary Figure 4. Piperlongumine $(\mathrm{PL})$ generates reactive oxygen species (ROS) in castration-resistant prostate cancer (CRPC) PC3 and DU145 cells. (A), Intracellular ROS generation in PC3 cells exposed to PL. Cells were treated with 1.0, 2.0 or 4.0 $\mathrm{MM} \mathrm{PL}$ for $48 \mathrm{~h}$ and then stained with ROS probe DCFH-DA. NAC pretreatment was carried out at $5 \mathrm{mM}$ for $1 \mathrm{~h}$. Representative histogram is shown. (B), Quantification of ROS levels in PC3 cells as determined by DCFH-DA probe. (C), The same as A, except DU145 cells were used. (D), Quantification of ROS levels in DU145 cells as determined by DCFH-DA probe. Values are average \pm SD of three independent experiments. The unpaired student's two-tailed t-test was used to determine the statistical significance $\left({ }^{*} p<0.05,{ }^{* *} p<0.01,{ }^{* * *} p<0.001\right)$. Supplementary Figure 5. $P L$ treatment induces cell death in CRPC cells. FACS analysis was performed to detect apoptotic PC3 (A) cells treated with the indicated concentration of PL (1.0, 2.0, or $4.0 \mu \mathrm{M})$ over 12 days. $\beta$-galactosidase staining assays were carried out to assess the senescence of DU145 (C) cells after PL treatment for 12 days. (B) and (D) represent quantification of $A$ and $C$, respectively. Values represent the mean \pm SD of at least three independent experiments. The statistical significance was calculated using the unpaired student's two-tailed t-test with the $p$-values $\left({ }^{*} p<0.05,{ }^{* *} p<\right.$ $\left.0.01,{ }^{* * *} p<0.001\right)$. Supplementary Figure 6. DAPI stained PC3 and DU145 cells after treatment of PL at indicated concentrations (1.0, 2.0, or $4.0 \mu \mathrm{M})$ immediately after long-term cell proliferation of incubation. Scale bar, $100 \mu \mathrm{m}$. Supplementary Figure 7. Piperlongumine $(\mathrm{PL})$ treatment triggers strong DNA damage and provokes intense DNA damage response in prostate cancer (CRPC) DU145 cells. (A) The data from comet assay showed that PL treatment triggers strong DNA damage in a concentration-dependent manner. Scale bar, $100 \mu \mathrm{m}$. (B) and (C), the percentages of DNA in the tail for PL treated DU145 cells (B) and the percentage of PL treated DU145 with over 10\% tail DNA (C) were measured. (D) The data from immunofluorescence showed that PL treatment provokes intense DNA damage response in a concentration-dependent manner. Scale bar, $10 \mu \mathrm{m}$. (E) Quantification of (D). Cells were treated with indicated concentration of PL $(1.0,2.0$, or $4.0 \mu \mathrm{M})$ for $48 \mathrm{~h}$ and $\geq 200$ cells were examined in each group. Values are average \pm SD of three independent experiments. The unpaired student's two-tailed t-test was used to determine the statistical significance $\left({ }^{*} p<0.05,{ }^{* *} p<0.01,{ }^{* * *} p<0.001\right.$ ). Supplementary Figure 8. Western blot assay for evaluating the expression of RPA, XRCC4 and KU70 in indicated concentration PL treated PC3 and DU145 cells. (A). The expression of RPA, XRCC4 and KU70 in PC3 cells. (B). The expression of RPA, XRCC4 and KU70 in DU145 cells. Supplementary Figure 9. Immunofluorescence (IF) assay for evaluating the DNA damage. (A) LO2 cells were treated with 0.01\% DMSO (Control), piperlongumine $(\mathrm{PL}, 4.0 \mu \mathrm{M})$, taxol $(4.0 \mu \mathrm{M})$, cisplatin (DDP, $4.0 \mu \mathrm{M})$, doxorubicin (Dox, $4.0 \mu \mathrm{M})$, 5-Fluorouracil (5-FU, $4.0 \mu \mathrm{M})$ for $48 \mathrm{~h}$. DAPI and 53BP1 was the nucleus dye (blue) and DNA damage marker (green), respectively. Scale bar, $10 \mu \mathrm{m}$. (B) Quantification of A. The results show the percentage of 53BP1 foci per cell among 200 untreated and treated cells, respectively. The Bar chart of all data represents mean \pm SD of three independent experiments, ${ }^{*} p<0.05,{ }^{* *} p<0.01$ and ${ }^{* * *} p<0.001$. Supplementary Figure 10. Piperlongumine $(\mathrm{PL})$ treatment $(10 \mu \mathrm{M}, 3 \mathrm{~h})$ did not induce the senescence, the apoptosis and/or cell arrest of castrationresistant prostate cancer (CRPC) PC3 and DU145 cells. (A) Representative results of $\beta$-gal staining assay of PL treated PC3 cells. Scale bar, $100 \mu \mathrm{m}$. (B) Quantitation of the percentage of senescent ( $\beta$-gal positive) cells in A. (C) The percentage of apoptotic cells in PL treated DU145 cells were analyzed by flow cytometry. (D) Quantitation of the percentage of apoptotic (Annexin V positive) cells in C. (E), Cell cycle arrest of PL treated PC3 cells were detected by FACS. (F) Quantitation of E. (G) As in E, except DU145 cells were used. (H) Quantitation of G. Control indicates cells without PL treatment and values are average \pm SD of three independent experiments. Supplementary Figure 11. $10 \mu \mathrm{M}$ PL treatment at indicated time suppressed the process of DNA damage repair in PC3 and DU145 cells and induced apoptosis in DU145 cells. (A), (B) The expression of p53, RPA and XRCC4 in PC3 and DU145 cells, respectively. (C), (D) The percentage of apoptotic cells in PL treated DU145 and PC3 cells were analyzed by flow cytometry, respectively. (E), (F) Quantitation of (C) and (D), respectively.

Additional file 2. Original blot images.

\section{Acknowledgments}

We thank LetPub (www.letpub.com) for its linguistic assistance during the preparation of this manuscript.

\section{Authors' contributions}

$D Z, Z Y, G L$ and $X Z$ conceive the idea. $X Z$ and $G L$ designed the experiments. $D Z, Z Y, J C$ and MW conducted experiments. XJ, YQ, XC, HS, ZL and MW analyzed data. $X Z$ and $G L$ wrote the manuscript. All authors were involved in the discussion of the project. All authors took part in the final version for submission and accept overall accountability for the accuracy and integrity of the manuscript. 


\section{Funding}

The present study was funded by National Science Foundation of China (No. 21701194), the National Natural Science Foundation of Zhejiang province (LY17B020008), Wenzhou Basic Medical and Health Technology Project (No. Y20180177), Wenzhou Medical University Talent Start-up Fund (No. QTJ17022) and Research Grant from Health Commission of Zhejiang Province (2019KY646)

\section{Availability of data and materials}

The datasets used and analyzed during the current study available from the corresponding author on reasonable request.

\section{Declarations}

Ethics approval and consent to participate Not applicable.

\section{Consent for publication}

Not applicable.

\section{Competing interests}

The authors report no declarations of interest.

\section{Author details}

${ }^{1}$ Chemical Biology Research Center, School of Pharmaceutical Sciences, Wenzhou Medical University, Wenzhou 325035, Zhejiang, People's Republic of China. ${ }^{2}$ The Fifth Affiliated Hospital of Wenzhou Medical University, Affiliated Lishui Hospital of Zhejiang University, The Central Hospital of Zhejiang Lishui, Lishui 323000, Zhejiang, People's Republic of China. ${ }^{3}$ The Affiliated Xiangshan Hospital, Wenzhou Medical University, Ningbo 315000, Zhejiang, China. ${ }^{4}$ Hospital of Chinese Medicine of Haishu District, Ningbo 315000, Zhejiang, China.

Received: 3 October 2020 Accepted: 28 June 2021

Published online: 06 July 2021

\section{References}

1. Hotte SJ, Saad F. Current management of castrate-resistant prostate cancer. Curr Oncol. 2010;17(Suppl 2):S72-9.

2. Torre LA, Bray F, Siegel RL, Ferlay J, Lortet-Tieulent J, Jemal A. Global cancer statistics, 2012. CA Cancer J Clin. 2015;65(2):87-108. https://doi.org/10.3322/ caac.21262.

3. Barry MJ, Simmons LH. Prevention of prostate Cancer morbidity and mortality: primary prevention and early detection. Med Clin North Am. 2017; 101(4):787-806. https://doi.org/10.1016/j.mcna.2017.03.009.

4. Berish RB, Ali AN, Telmer PG, Ronald JA, Leong HS. Translational models of prostate cancer bone metastasis. Nat Rev Urol. 2018;15(7):403-21. https:// doi.org/10.1038/s41585-018-0020-2.

5. de Oliveira Barros EG, Meireles Da Costa N, Palmero CY, et al. Malignant invasion of the central nervous system: the hidden face of a poorly understood outcome of prostate cancer. World J Urol. 2018;36(12):2009-19. https://doi.org/10.1007/s00345-018-2392-6.

6. Dellis A, Zagouri F, Liontos $\mathrm{M}$, et al. C management of advanced prostate cancer: a systematic review of existing guidelines and recommendations. Cancer Treat Rev. 2018;73:54-61.

7. Lord CJ, Ashworth A. The DNA damage response and cancer therapy. Nature. 2012;481(7381):287-94. https://doi.org/10.1038/nature10760.

8. Gavande NS, VanderVere-Carozza PS, Hinshaw HD, et al. DNA repair targeted therapy: the past or future of cancer treatment? Pharmacol Ther. 2016;160:65-83. https://doi.org/10.1016/j.pharmthera.2016.02.003.

9. Krol M, Pawlowski KM, Majchrzak K, et al. Why chemotherapy can fail? Pol J Vet Sci. 2010;13(2):399-406.

10. Reddy PS, Jamil K, Madhusudhan P, et al. Antibacterial activity of isolates from Piper longum and Taxus baccata. Pharm Biol. 2001;39(3):236-8. https:// doi.org/10.1076/phbi.39.3.236.5926.

11. Bezerra DP, Pessoa C, Moraes MO, et al. In vivo growth inhibition of sarcoma 180 by piperlonguminine, an alkaloid amide from the Piper species. J Appl Toxicol. 2008;28(5):599-607. https://doi.org/10.1002/jat.1311.

12. Bezerra DP, Pessoa C, de Moraes MO, Saker-Neto N, Silveira ER, Costa-Lotufo LV. Overview of the therapeutic potential of piplartine (piperlongumine). Eur J Pharm Sci. 2013;48(3):453-63. https://doi.org/10.1016/j.ejps.2012.12.003.
13. Mohler H, Pfirrmann RW, Frei K. Redox-directed cancer therapeutics: Taurolidine and Piperlongumine as broadly effective antineoplastic agents (review). Int J Oncol. 2014;45(4):1329-36. https://doi.org/10.3892/ijo.2014.2566.

14. Ginzburg S, Golovine KV, Makhov PB, Uzzo RG, Kutikov A, Kolenko VM. Piperlongumine inhibits NF-kappaB activity and attenuates aggressive growth characteristics of prostate cancer cells. Prostate. 2014;74(2):177-86. https://doi.org/10.1002/pros.22739.

15. Bharadwaj U, Eckols TK, Kolosov M, Kasembeli MM, Adam A, Torres D, et al. Drug-repositioning screening identified piperlongumine as a direct STAT3 inhibitor with potent activity against breast cancer. Oncogene. 2015;34(11): 1341-53. https://doi.org/10.1038/onc.2014.72.

16. Sun LD, Wang F, Dai F, Wang YH, Lin D, Zhou B. Development and mechanism investigation of a new piperlongumine derivative as a potent anti-inflammatory agent. Biochem Pharmacol. 2015;95(3):156-69. https://doi. org/10.1016/j.bcp.2015.03.014.

17. Matschke J, Riffkin H, Klein D, Handrick R, Lüdemann L, Metzen E, et al. Targeted inhibition of glutamine-dependent glutathione metabolism overcomes death resistance induced by chronic cycling hypoxia. Antioxid Redox Signal. 2016:25(2):89-107. https://doi.org/10.1089/ars.2015.6589.

18. Gu SM, Yun J, Son DJ, Kim HY, Nam KT, Kim HD, et al. Piperlongumine attenuates experimental autoimmune encephalomyelitis through inhibition of NF-kappaB activity. Free Radical Bio Med. 2017;103:133-45. https://doi. org/10.1016/j.freeradbiomed.2016.12.027.

19. Hang W, Yin ZX, Liu G, Zeng Q, Shen XF, Sun QH, et al. Piperlongumine and p53-reactivator APR-246 selectively induce cell death in HNSCC by targeting GSTP1. Oncogene. 2018;37(25):3384-98. https://doi.org/10.1038/s41388-0170110-2.

20. Piska K, Gunia-Krzyzak A, Koczurkiewicz P, et al. Piperlongumine (piplartine) as a lead compound for anticancer agents - synthesis and properties of analogues: a mini-review. Eur J Med Chem. 2018;156:13-20. https://doi.org/1 0.1016/j.ejmech.2018.06.057.

21. Golovine KV, Makhov PB, Teper E, Kutikov A, Canter D, Uzzo RG, et al. Piperlongumine induces rapid depletion of the androgen receptor in human prostate cancer cells. Prostate. 2013;73(1):23-30. https://doi.org/10.1 002/pros.22535.

22. Piska K, Koczurkiewicz P, Wnuk D, Karnas E, Bucki A, Wójcik-Pszczoła K, et al. Synergistic anticancer activity of doxorubicin and piperlongumine on DU-145 prostate cancer cells - the involvement of carbonyl reductase 1 inhibition. Chem Biol Interact. 2019;300:40-8. https://doi.org/10.1016/j.cbi.2019.01.003.

23. Zheng XH, Zhong YF, Tan CP, Ji LN, Mao ZW. Pt(II) squares as selective and effective human telomeric G-quadruplex binders and potential cancer therapeutics. Dalton Trans. 2012;41(38):11807-12. https://doi.org/10.1039/c2 dt31303k.

24. Zheng XH, Nie X, Liu HY, Fang YM, Zhao Y, Xia LX. TMPyP4 promotes cancer cell migration at low doses, but induces cell death at high doses. Sci Rep. 2016;6(1):26592. https://doi.org/10.1038/srep26592.

25. Zheng $X H$, Nie $X$, Fang $Y$, et al. A Cisplatin Derivative Tetra-Pt(bpy) as an Oncotherapeutic Agent for Targeting ALT Cancer. J Natl Cancer Inst. 2017; 109(10):djx061.

26. Chen YL, Deng ZQ, Jiang S, Hu Q, Liu H, Songyang Z, et al. Human cells lacking coilin and Cajal bodies are proficient in telomerase assembly, trafficking and telomere maintenance. Nucleic Acids Res. 2015;43(1):385-95. https://doi.org/10.1093/nar/gku1277.

27. Olive PL, Banath JP. The comet assay: a method to measure DNA damage in individual cells. Nat Protoc. 2006;1 (1):23-9. https://doi.org/10.1038/nprot.2006.5.

28. Boyd D. Invasion and metastasis. Cancer Metastasis Rev. 1996;15(1):77-89. https://doi.org/10.1007/BF00049488.

29. Chugh P, Paluch EK. The actin cortex at a glance. J Cell Sci. 2018;131(14): jes186254.

30. Mitra SK, Hanson DA, Schlaepfer DD. Focal adhesion kinase: in command and control of cell motility. Nature reviews. Mol Cell Biol. 2005;6(1):56-68.

31. Oliver FJ, de la Rubia G, Rolli V, Ruiz-Ruiz MC, de Murcia G, Murcia JMD. Importance of poly(ADP-ribose) polymerase and its cleavage in apoptosis. Lesson from an uncleavable mutant. J Biol Chem. 1998:273(50):33533-9. https://doi.org/10.1074/jbc.273.50.33533.

32. Ashkenazi A, Fairbrother WJ, Leverson JD, Souers AJ. From basic apoptosis discoveries to advanced selective BCL-2 family inhibitors. Nature reviews. Drug Discov. 2017;16(4):273-84. https://doi.org/10.1038/nrd.2016.253.

33. Roos WP, Thomas AD, Kaina B. DNA damage and the balance between survival and death in cancer biology. Nat Rev Cancer. 2016;16(1):20-33. https://doi.org/10.1038/nrc.2015.2. 
34. Janic A, Valente LJ, Wakefield MJ, di Stefano L, Milla L, Wilcox S, et al. DNA repair processes are critical mediators of p53-dependent tumor suppression. Nat Med. 2018;24(7):947-53. https://doi.org/10.1038/s41591-018-0043-5.

35. Liu B, Yi J, Yang X, Liu L, Lou X, Zhang Z, et al. MDM2-mediated degradation of WRN promotes cellular senescence in a p53-independent manner. Oncogene. 2019;38(14):2501-15. https://doi.org/10.1038/s41388-01 8-0605-5.

36. Tang K, Constanzo JD, Venkateswaran N, Melegari M, Ilcheva M, Morales JC, et al. Focal adhesion kinase regulates the DNA damage response and its inhibition Radiosensitizes mutant KRAS lung Cancer. Clin Cancer Res. 2016; 22(23):5851-63. https://doi.org/10.1158/1078-0432.CCR-15-2603.

37. Srinivas US, Tan BWQ, Vellayappan BA, Jeyasekharan AD. ROS and the DNA damage response in cancer. Redox Biol. 2019;25:101084. https://doi.org/10.1 016/j.redox.2018.101084.

38. Filippo JS, Sung P, Klein H. Mechanism of eukaryotic homologous recombination. Annu Rev Biochem. 2008;77(1):229-57. https://doi.org/10.114 6/annurev.biochem.77.061306.125255.

39. Lieber MR. The mechanism of double-strand DNA break repair by the nonhomologous DNA end-joining pathway. Annu Rev Biochem. 2010;79(1): 181-211. https://doi.org/10.1146/annurev.biochem.052308.093131.

40. Nana FA, Vanderputten M, Ocak S. Role of focal adhesion kinase in smallcell lung cancer and its potential as a therapeutic target. Cancers. 2019; 11(11):1683.

41. Karki K, Hedrick E, Kasiappan R, et al. Piperlongumine induces reactive oxygen species (ROS)-dependent downregulation of specificity protein transcription factors. Cancer Prev Res. 2017;10(8):467-77.

\section{Publisher's Note}

Springer Nature remains neutral with regard to jurisdictional claims in published maps and institutional affiliations.

Ready to submit your research? Choose BMC and benefit from:

- fast, convenient online submission

- thorough peer review by experienced researchers in your field

- rapid publication on acceptance

- support for research data, including large and complex data types

- gold Open Access which fosters wider collaboration and increased citations

- maximum visibility for your research: over $100 \mathrm{M}$ website views per year

At $\mathrm{BMC}$, research is always in progress.

Learn more biomedcentral.com/submissions 